\title{
Zooplankton Feeding Induces Macroscopical Gonad Malformations in Whitefish (Coregonus ssp.) from Lake Thun, Switzerland
}

\author{
Daniel Bernet ${ }^{1,2}$, Thomas Wahli ${ }^{1}$, Christoph Küng ${ }^{2}$ and Helmut Segner ${ }^{1, * \mathbb{D}}$ \\ 1 Centre for Fish and Wildlife Health, University of Bern, Länggass-Strasse 122, Post-Box, CH-3001 Bern, \\ Switzerland; daniel.bernet@be.ch (D.B.); Thomas.wahli@vetsuisse.unibe.ch (T.W.) \\ 2 Fisheries Inspectorate Bern, Schwand, CH-3110 Münsingen, Switzerland; kueng.christoph@bluewin.ch \\ * Correspondence: helmut.segner@vetsuisse.unibe.ch
}

Received: 11 June 2020; Accepted: 10 August 2020; Published: 20 August 2020

\begin{abstract}
Alterations in gonad morphology are widespread in wild fish populations. Whitefish (Coregonus spp.) from Lake Thun, Switzerland, display a high prevalence of macroscopical gonad malformations including fusions to the musculature, segmented gonads and intersex condition. The aim of the present study was to evaluate whether the gonad morphological changes in Lake Thun whitefish are caused by genetic factors, environmental factors (water, diet) or "gene $\times$ environment" interaction. We performed two independent experiments of a three-year duration in which we reared whitefish from fertilization until adulthood and tested the possible causative factors using a matrix design: (i) genetics-comparing the prevalence of gonad malformations in whitefish of different genetic origin reared under identical environmental conditions (same diet, same water, same experimental facility); (ii) environment-comparing the prevalence of gonad malformations in whitefish of the same genetic origin reared in different water sources and/or fed with different diets; and (iii) gene-environment interaction-comparing the prevalence of gonad morphological alterations in relation to the combinations of genetics and environmental factors. Two diets were used for the rearing experiments: either zooplankton collected in Lake Thun which represents the natural diet of whitefish, or an artificial dry food which was used as control. The key finding of this study is that the inducing factor of the gonad malformations is contained in the zooplankton of Lake Thun. Fish fed with this diet developed a significantly higher prevalence of malformations than fish from any other treatment, irrespective of the genetic origin and/or the water source. This result could be repeated in the two independent experiments. Importantly, the prevalence values observed in the experimental fish fed with Lake Thun zooplankton were similar to the prevalence values recorded in free-ranging whitefish in the lake. The findings of this study advance the understanding of the causes of gonad morphological alterations in wild fish populations.
\end{abstract}

Keywords: coregonids; fish; gonad pathology; intersex; environmental disease

\section{Introduction}

Morphological abnormalities of the gonads is a phenomenon that has been reported from numerous wild fish populations [1-14]. These morphological alterations are of concern as they may be indicative of a disease and/or may impair the reproductive success of the populations $[11,15,16]$. Given the fact that fish sexual differentiation and gonad development are subject to genetic and environmental influences [7,17], alterations in gonad morphology can be induced both by endogenous and exogenous factors as well as their interaction. Accordingly, gonad abnormalities of fish have been associated, among others, with genetic quality and hybridization status of the broodstock $[18,19]$, 
autoimmune disease [20], changes in physical water parameters [21,22] or parasite infection [23,24]. One environmental factor that has attracted particular attention as a cause of gonad abnormalities in fish is aquatic contamination by anthropogenic chemicals [4,15,25-30]. Obviously, a broad variety of factors can be involved in the induction of gonad morphological alterations in fish, and to advance our understanding of this phenomenon, it needs a systematic approach to unravel the causative factors and processes.

Whitefish (Coregonus spp.) populations from Lake Thun, Switzerland, were reported to exhibit extensive changes in their gonad morphology, affecting up to 35\% of the population [31]. The gonad alterations are specific to whitefish since other fish species living in the lake do not show alterations in their gonad morphology. Despite the high prevalence of the gonad alterations, there exists currently no evidence that the reproduction of coregonid populations in Lake Thun is negatively impacted (unpublished data). Based on the macroscopical appearance, six types of morphological alterations have been classified [31]: (1) adhesion/fusion of the gonads to the peritoneal wall and the musculature, (2) compartmentation of the gonads into separated lobes ("segmented gonads" according to [27], (3) one or both gonad strands are undeveloped (atrophy) or totally absent (aplasia), (4) asymmetry in the size of the left and right gonad strands, (5) constrictions of the gonads, and (6) macroscopic hermaphroditism, i.e., the presence of complete male and female gonads in the same individual [27]. In addition, microscopic intersex, i.e., the presence of male germ cells in ovaries or the presence of female germ cells in testes was observed. Using this macroscopical classification scheme, a large-scale monitoring program in Lake Thun and two neighboring lakes provided epidemiological evidence that gonad morphological alterations occurred in whitefish of the other lakes as well. However, whitefish from Lake Thun displayed significantly higher prevalences of gonad compartmentations, gonad fusions, gonad aplasias and intersex/hermaphrodism compared to whitefish of the other lakes [32]. In contrast, segmented gonads and gonad asymmetries occurred at comparable frequencies in whitefish populations of all three lakes. Therefore, Bittner et al. [32]) interpreted the latter alterations to represent natural "background" variations of gonad morphology in whitefish, whereas compartmentations, fusions, aplasias and intersex/hermaphrodism, were classified as true malformations.

To date, the causative factor(s) of the gonad morphological changes in Lake Thun whitefish have not been identified. Whitefish species can show considerable morphological variability, which may be related to the genetic divergence and adaptive radiation of coregonids in many lakes of the Northern hemisphere [33-37]. On the other hand, environmental factors such as parasites or anthropogenic contaminants are also known to cause phenotypic variations of whitefish gonads [24,38].

The aim of the present study was to evaluate whether the high prevalence of gonad morphological changes in Lake Thun whitefish is caused either by a factor contained in the genotype of Lake Thun whitefish, a factor contained in the environment, i.e., the lake water or the natural zooplankton diet of the fish, or a "gene $\times$ environment" interaction. For testing the various possibilities, we performed a three-year experiment in which we reared whitefish from fertilization until adulthood under controlled conditions and treated the fish according to the following matrix design: (i) genetics-comparing the prevalence of gonad malformations in whitefish of different genetic origin reared under identical environmental conditions (same food, same water, same experimental facility); (ii) environment-comparing the prevalence of gonad malformations in whitefish of the same genetic origin reared in different water sources and/or fed with different diets; and (iii) gene-environment interaction-comparing the prevalence of gonad malformations in whitefish of different genetic origin kept under the various environmental conditions. The study was replicated in two independent experiments in order to test for the repeatability of the findings cf. [39]. The response variable assessed in the experiments was "gonad malformation". For this, we relied on the classification scheme for whitefish gonad malformations as established by Bernet et, al. [31]. This scheme builds on macroscopical changes in gonad morphology, only intersex gonads (i.e., the presence of male or female germ cells in ovaries or testes, respectively) are assessed by means of histology. Gonad morphological alterations representing natural variability (segementations, asymmetries-see above) were excluded from the analysis, but only 
true malformations (compartmentations, fusions, aplasias, intersex/hermaphrodism, cf. [32]) were considered in the present analysis.

\section{Results}

Fish of the different treatment groups showed a considerable variation in body size (Figure 1). Mean body lengths of fish varied between $14.5 \mathrm{~cm}$ (Al2SP) and $21.7 \mathrm{~cm}$ (Al1LD), with a tendency for dry food feeding to result in larger fish. Independent of the treatment group, body size of the experimental fish after three years of rearing was smaller than that of wild fish of the same age in Lake Thun (mean body size experimental fish: $32 \mathrm{~cm}$, mean body size of wild fish of the same age: $37 \mathrm{~cm}$ [40]) or in Lake Biel, respectively (mean body size experimental fish: $27 \mathrm{~cm}$, mean body size of wild fish of the same age: $32 \mathrm{~cm}$ [40]). This indicates that our experimentally reared fish did not grow equally well as the wild fish.

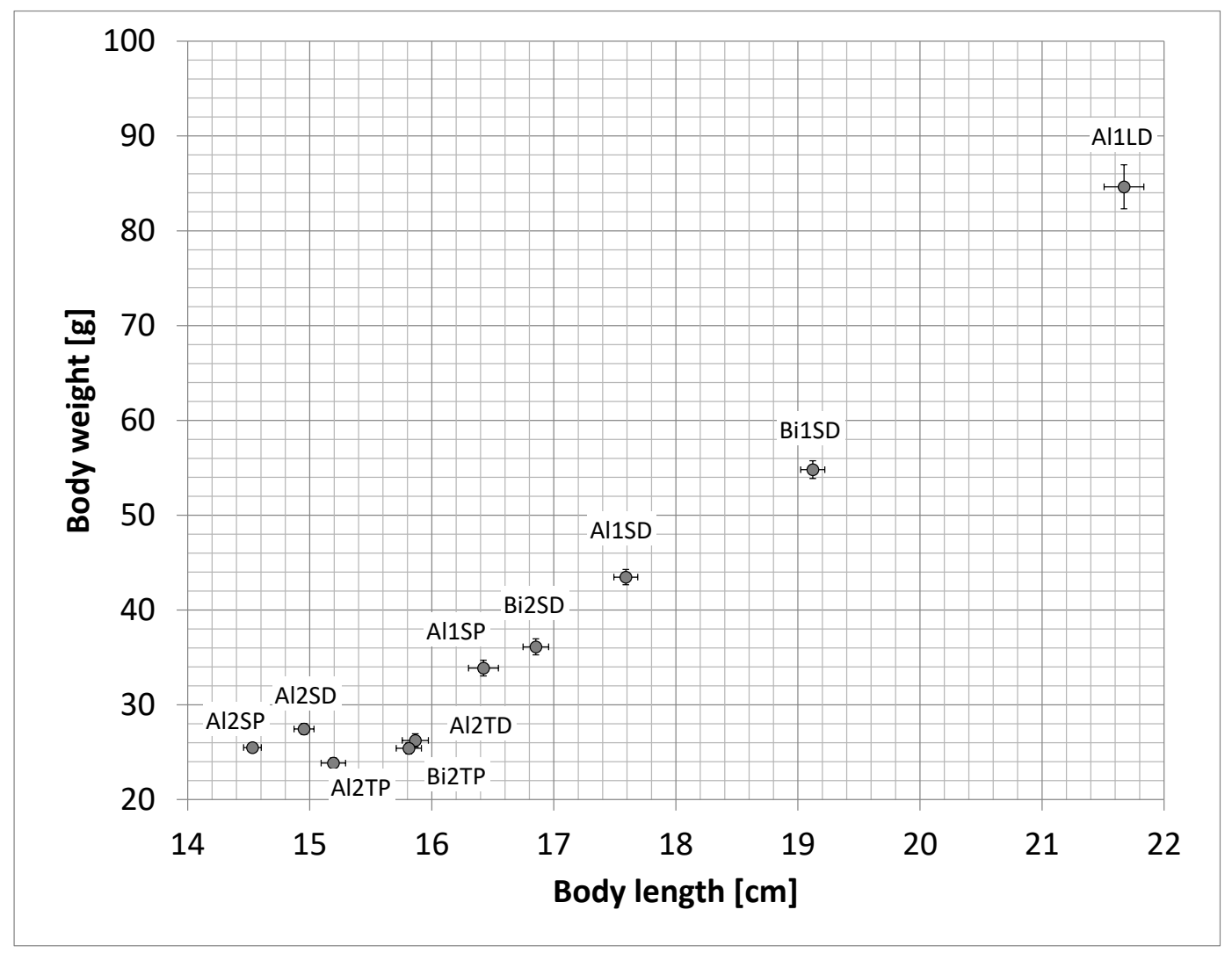

Figure 1. Mean values $( \pm$ S.E.) of body length and weight of fish from the different treatment groups. See Table 1 for the connotation of the group names.

In all experimental groups, male fish showed significantly higher prevalences of gonad malformations compared to females-an observation that agrees with findings in wild whitefish from Lake Thun [31,32]. Thus, in the following, we will present the results separately for males and females.

At the end of the three-year experimental period, the highest prevalences of gonad malformations were observed in the groups receiving Lake Thun zooplankton. This was observed both in males (Figure 2a) and females (Figure 2b). Zooplankton-fed whitefish displayed higher prevalences of malformations irrespective of the water source the fish were reared in (Lake Thun water, Lake Lucerne water, spring water), and irrespective of the genetic origin of the fish (Bondelle ecotype from Lake Biel versus Albock ecotype from Lake Thun). In the first experiment, 26\% (Al1SP), of male offspring from Lake Thun whitefish reared in spring water and fed with zooplankton (Al1SP), developed malformed gonads (Figure 2a). Their siblings fed with dry food showed gonad malformations in only $2-3 \%$ of 
the experimental fish, irrespective of whether they were reared in spring water (Al1SD) or in Lake Lucerne water (Al1LD). Similarly, offspring of whitefish from Lake Biel fed with zooplankton showed a significantly higher prevalence of gonad malformations than Lake Biel offspring fed with dry food (Figure 2a). The results from the second experiment significantly agreed with the results of the first rearing experiment (Fisher's Combination Test for Two-Stage Sampling; $p<0.01$ ): when male Albock from Lake Thun were fed with zooplankton, they developed significantly higher prevalences of gonad malformations than male fish fed with dry feed (16\% in the Al2SP treatment and $28 \%$ in Al2TP, versus $2 \%$ in Al2SD and $3 \%$ in Al2TD; Fisher's exact test, pairwise treatment group testing; $p \leq 0.0002$ ). Neither the water source nor the genetic origin of the fish had a significant influence on the frequency of the malformations in male whitefish. Comparable to the Albock ecotype from Lake Thun, male Bondelle from Lake Biel also showed significantly higher malformation prevalences with zooplankton feeding (Bi2TP: 20\%) than with dry food (Bi1SD: 6\%, Bi2SD: 2\%).

Table 1. List of the abbreviations used to designate the experimental treatment groups.

\begin{tabular}{|c|c|}
\hline Abbreviations Used for Treatment Groups & Description of the Treatment Group \\
\hline \multicolumn{2}{|l|}{ 1st experiment } \\
\hline Al1LD & $\begin{array}{l}\text { Whitefish of the ecotype "Albock" from Lake Thun, fertilized } \\
\text { and reared in Lake Lucerne water, and fed with artificial dry } \\
\text { feed ( } \mathrm{Al}=\text { Albock, } \mathrm{L}=\text { Lake Lucerne water, } \mathrm{D}=\text { dry food). }\end{array}$ \\
\hline Al1SP & $\begin{array}{l}\text { Whitefish of the ecotype "Albock" from Lake Thun, fertilized } \\
\text { and reared in spring water, and fed with zooplankton from } \\
\text { Lake Thun ( } \mathrm{Al}=\text { Albock, } \mathrm{S}=\text { spring water, } \mathrm{P}=\text { zooplankton). }\end{array}$ \\
\hline Al1SD & $\begin{array}{l}\text { Whitefish of the ecotype "Albock" from Lake Thun, fertilized } \\
\text { and reared in spring water, and fed with artificial dry feed } \\
\qquad(\mathrm{Al}=\text { Albock, } \mathrm{S}=\text { spring water, } \mathrm{D}=\text { dry food). }\end{array}$ \\
\hline Bi1SD & $\begin{array}{l}\text { Whitefish of the ecotype "Bondelle" from Lake Biel, fertilized } \\
\text { and reared in spring water, and fed with artificial dry feed } \\
\text { (Bi = Lake Biel whitefish, } \mathrm{S}=\text { spring water, } \mathrm{D}=\text { dry food). }\end{array}$ \\
\hline \multicolumn{2}{|l|}{ 2nd experiment } \\
\hline $\mathrm{Al} 2 \mathrm{TP}$ & $\begin{array}{l}\text { Whitefish of the ecotype "Albock" from Lake Thun, fertilized } \\
\text { and reared in Lake Thun water, and fed with zooplankton from } \\
\text { Lake Thun ( } \mathrm{Al}=\text { Albock, } \mathrm{T}=\text { Lake Thun water, } \\
\qquad \mathrm{P}=\text { zooplankton). }\end{array}$ \\
\hline $\mathrm{Al} 2 \mathrm{TD}$ & $\begin{array}{l}\text { Whitefish of the ecotype "Albock" from Lake Thun, fertilized } \\
\text { and reared in Lake Thun water, and fed with artificial dry feed } \\
\text { (Al = Albock, } \mathrm{T}=\text { Lake Thun water, } \mathrm{D}=\text { dry food). }\end{array}$ \\
\hline $\mathrm{Al} 2 \mathrm{SP}$ & $\begin{array}{c}\text { Whitefish of the ecotype "Albock" from Lake Thun, fertilized } \\
\text { and reared in spring water, and fed with zooplankton from } \\
\text { Lake Thun (Al = Albock, } \mathrm{S}=\text { spring water, } \mathrm{P}=\text { zooplankton). } \\
\text { This is a repetition of Al1SP. }\end{array}$ \\
\hline $\mathrm{Al} 2 \mathrm{SD}$ & $\begin{array}{c}\text { Whitefish of the ecotype "Albock" from Lake Thun, fertilized } \\
\text { and reared in spring water, and fed with artificial dry feed } \\
(\mathrm{Al}=\text { Albock, } \mathrm{S}=\text { spring water, } \mathrm{D}=\text { dry food). This is a } \\
\text { repetition of Al1SD. }\end{array}$ \\
\hline Bi2TP & $\begin{array}{l}\text { Whitefish ecotype "Bondelle" from Lake Biel, fertilized and } \\
\text { reared in Lake Thun water, and fed with zooplankton from } \\
\text { Lake Thun (Bi = Lake Biel whitefish, T = Lake Thun water, } \\
\qquad \mathrm{P}=\text { zooplankton). }\end{array}$ \\
\hline Bi2SD & $\begin{array}{l}\text { Whitefish of the ecotype "Bondelle" from Lake Biel, fertilized } \\
\text { and reared in spring water, and fed with artificial dry feed } \\
\text { (Bi = Lake Biel whitefish, } \mathrm{S}=\text { spring water, } \mathrm{D}=\text { dry food). } \\
\text { This is a repetition of BilSD. }\end{array}$ \\
\hline
\end{tabular}




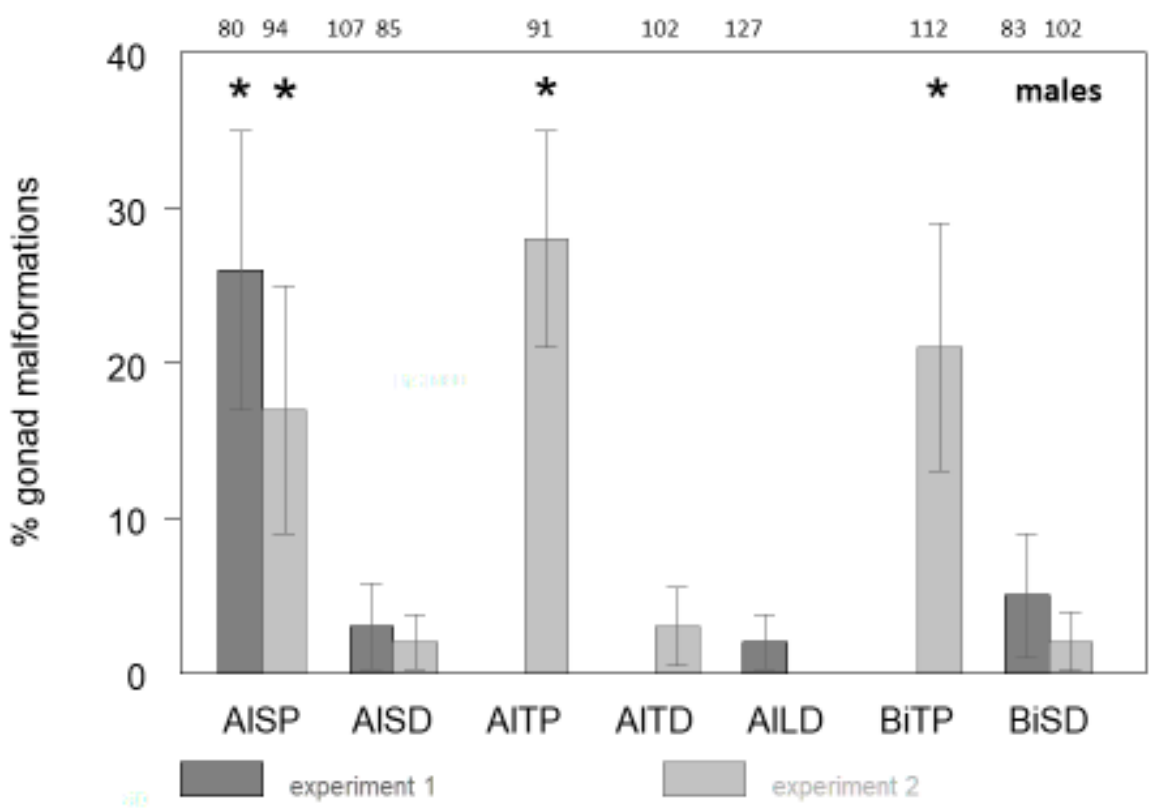

(a)

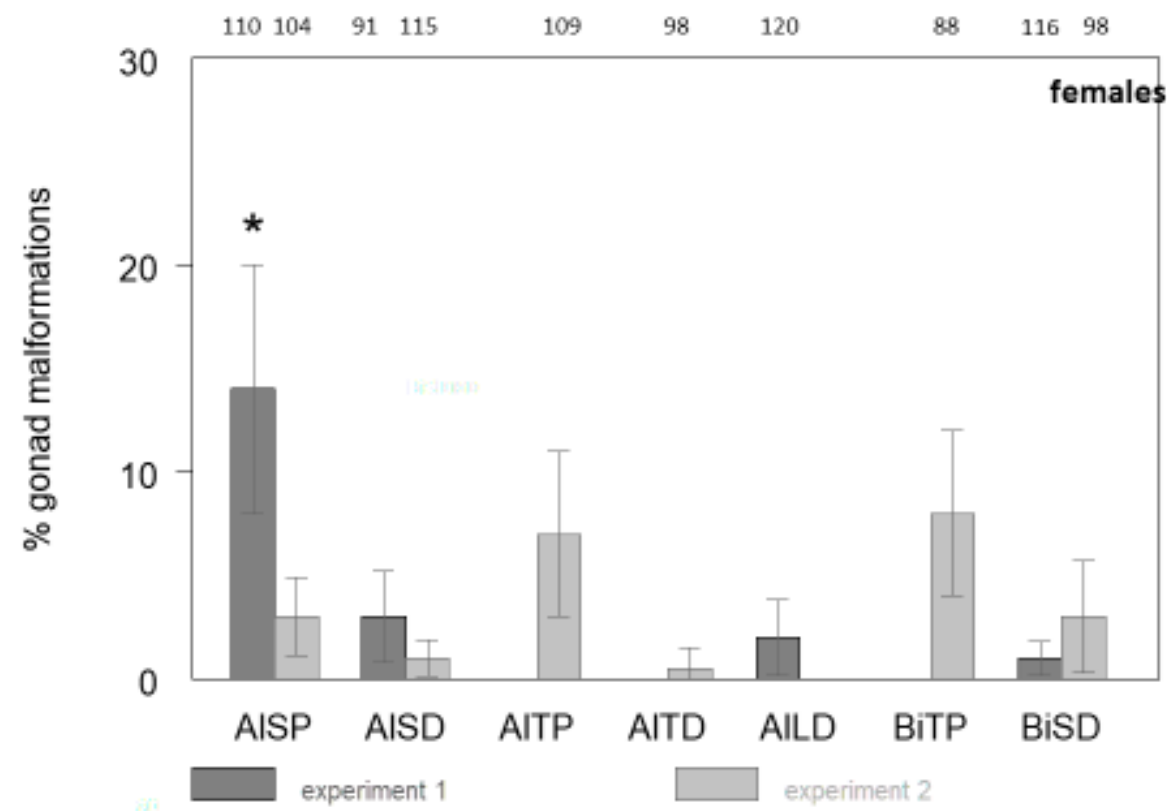

(b)

Figure 2. Prevalences of gonad malformations in (a) males and (b) females. Fish were classified to have malformed gonads if one the following alterations were present: fusions to the peritoneal wall, compartmentations, and aplasia. The error bars represent the $95 \%$ confidence intervals $\left(\mathrm{CI}_{95}\right)$ of the frequencies. The numbers above the figure denote the number of fish analyzed within the treatment group. Macroscopic intersex fish and juvenile fish that could not be sexed due to retarded gonad development are not included in the data. This explains the difference in the number of fish sampled per group indicated in Table 2. The asterisks denote treatment groups with significantly higher frequencies of gonad malformations than the groups within the respective trial without asterisks at a significance level of $p \leq 0.004$ (pairwise Fisher's exact test). 
Table 2. Experimental setup of the different treatment groups. Connotations for the group names: genetic origin/water/food, i.e., $\mathrm{Al}_{1} \mathrm{SD}=$ 'Albock' whitefish from Lake Thun, reared in spring water and fed with dry feed. The indexes " 1 " and " 2 " indicate the affiliation of the treatment groups to the first or second experiment. Abbreviations: $\mathrm{Al}=$ Albock whitefish from Lake Thun; $\mathrm{Bi}=$ whitefish from Lake Biel; $\mathrm{T}=$ Lake Thun water, $\mathrm{L}=$ Lake Lucerne water; $\mathrm{S}=$ spring water; $\mathrm{P}=$ plankton, $\mathrm{D}$ $=$ dry fed; $\mathrm{dph}=$ days post hatch; $\mathrm{d}^{\circ} \mathrm{C}=$ degree-days post hatch; $\mathrm{N}=$ number; $f=$ frequency in percent.

\begin{tabular}{|c|c|c|c|c|c|c|c|c|c|c|c|}
\hline Group & $\begin{array}{c}\text { Origin of } \\
\text { Parental Fish }\end{array}$ & $\begin{array}{l}\text { Nof Parental } \\
\text { Fish }\end{array}$ & $\begin{array}{c}f \text { of Gonad Deformations } \\
\text { in Parental Fish }\end{array}$ & Hatchery & $\begin{array}{l}\text { Water for } \\
\text { Fertilization }\end{array}$ & Fish Farm & $\begin{array}{l}\text { Water } \\
\text { Source }\end{array}$ & Feed & N Fish & $\begin{array}{c}\text { Age of } \\
\text { Fish [dph] }\end{array}$ & 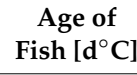 \\
\hline Al1LD & Lake Thun & 126 & 6 & Fluelen & $\begin{array}{c}\text { Lake } \\
\text { Lucerne }\end{array}$ & Fluelen & $\begin{array}{l}\text { Lake } \\
\text { Lucerne }\end{array}$ & Dry feed & 247 & 982 & 10,747 \\
\hline Al1SP & Lake Thun & 126 & 6 & Spiez & $\begin{array}{l}\text { Spring } \\
\text { water }\end{array}$ & Reutigen & $\begin{array}{l}\text { Spring } \\
\text { water }\end{array}$ & Plankton & 200 & 974 & 8296 \\
\hline Al1SD & Lake Thun & 126 & 6 & Spiez & $\begin{array}{l}\text { Spring } \\
\text { water }\end{array}$ & Reutigen & $\begin{array}{l}\text { Spring } \\
\text { water }\end{array}$ & Dry feed & 200 & 974 & 8296 \\
\hline Bi1SD & Lake Biel & 89 & 1 & Spiez & $\begin{array}{l}\text { Spring } \\
\text { water }\end{array}$ & Reutigen & $\begin{array}{l}\text { Spring } \\
\text { water }\end{array}$ & Dry feed & 200 & 987 & 8407 \\
\hline $\mathrm{Al} 2 \mathrm{TP}$ & Lake Thun & 52 & 15 & Faulensee & Lake Thun & Thun & Lake Thun & Plankton & 200 & 964 & 10,324 \\
\hline $\mathrm{Al} 2 \mathrm{SP}$ & Lake Thun & 52 & 15 & Reutigen & $\begin{array}{l}\text { Spring } \\
\text { water }\end{array}$ & Reutigen & $\begin{array}{l}\text { Spring } \\
\text { water }\end{array}$ & Plankton & 200 & 1002 & 8526 \\
\hline $\mathrm{Al} 2 \mathrm{SD}$ & Lake Thun & 52 & 15 & Reutigen & $\begin{array}{l}\text { Spring } \\
\text { water }\end{array}$ & Reutigen & $\begin{array}{l}\text { Spring } \\
\text { water }\end{array}$ & Dry feed & 200 & 1002 & 8526 \\
\hline Bi2SD & Lake Biel & 70 & 0 & Reutigen & $\begin{array}{l}\text { Spring } \\
\text { water }\end{array}$ & Reutigen & $\begin{array}{l}\text { Spring } \\
\text { water }\end{array}$ & Dry feed & 200 & 1020 & 8687 \\
\hline Bi2TP & Lake Biel & 70 & 0 & Faulensee & Lake Thun & Thun & Lake Thun & Plankton & 200 & 973 & 10,389 \\
\hline
\end{tabular}


Female fish displayed the same trends as observed for male fish, although the absolute prevalence values were lower (Figure 2b). In the first experiment, female offspring of Lake Thun whitefish reared in spring water and fed zooplankton (Al1SP) showed significantly more gonad malformations (14\%) than their siblings fed with dry food (Fisher's exact test; $p \leq 0.004$ ), regardless of the water in which they were reared (groups Al1SD and Al1LD with $2 \%$ ). In the second trial, there was a pattern in the frequency differences between females reared in Lake Thun water fed with zooplankton (Al2TP with $4 \%$ and Bi2TP with 5\%) compared to females reared in the same water but fed with dry fed (A12TD with $0 \%$ ) (Fisher's exact test; $p=0.12$ and $p=0.05$, respectively).

The significantly higher frequencies of gonad deformations in both males and females fed with plankton were mainly based on the occurrence of fused and compartmented gonads. Fusions of gonad lobes with the filet and compartmented gonads are also the most typical gonad alterations found in wild whitefish from Lake Thun [31,32]. The two other gonad malformations, aplasia and intersex gonads, were less frequent in fish of our experiment, and they occur less frequently in wild coregonids in the lake [31,32]. Overall, the experimental feeding of whitefish with Lake Thun zooplankton well reproduces the frequency and type of gonad malformations as they occur in the free-ranging conspecifics.

\section{Discussion}

The results of this long-term study provide strong evidence that zooplankton of Lake Thun contains the factor causing the induction of the gonad malformations. Of the factors tested in the experimental setup ('genetics', 'water' and 'food'), only zooplankton from Lake Thun was able to significantly induce the gonad deformations typical for Lake Thun whitefish. It is a strength of the present study that this result could be repeated in two independent experiments-each of them lasting for three years. The zooplankton effect was observed irrespective of the genetic origin of the fish (Lake Biel versus Lake Thun) and irrespective of the water source used for the fish rearing (Lake Lucerne water, Lake Thun water, spring water). Remarkably, the induction of gonad malformations occurred primarily in male fish, and only to a lesser degree in female fish, a finding which agrees with the observations on the wild coregonid population in the lake [31,32]. The mean frequency of gonad deformations in male fish fed with zooplankton was $21 \%$, and this value corresponds to the mean frequency of gonad malformations of the Albock ecotype in Lake Thun [31,32].

Dry food remained without effect on the gonad morphology; the mean prevalence of gonad deformations in all dry food groups was 3\%, and the maximum value was $8 \%$. Further, the water source did not appear to be a relevant factor, since the prevalence of gonad malformations in zooplankton-fed Albock and Bondelle was not different between fish reared in Lake Thun water or in spring water. In Lake Thun water as well as in spring water, both Lake Biel and Lake Thun whitefish developed an elevated prevalence of gonad malformations when fed with zooplankton from Lake Thun, while this did not occur when the fish were fed on dry food. There is no evidence for a 'genetic predisposition' of Lake Thun whitefish to develop malformed gonads: malformations in response to zooplankton feeding were equally developed by whitefish from Lake Thun and whitefish from Lake Biel. Thus, the increased prevalence of gonad malformations in Lake Thun coregonids is unlikely to represent a genetic predisposition. This interpretation is supported by the findings of Urbach et al. [41] and Bittner et al. [35]). Finally, the fact that the prevalence of gonad malformations in Lake Biel whitefish reared in Lake Thun water and fed with Lake Thun zooplankton did not differ significantly from the prevalence of gonad malformations in Lake Thun whitefish reared under identical conditions argues against a contribution of "gene $\times$ environment" interaction. Taken together, the experimental data consistently indicate that the inducing factor for the gonad malformations is contained in Lake Thun zooplankton. Whitefish are zooplankton feeders, and thus, are vulnerable to any inducing factor being present in the plankton. As suggested by Bittner et al. [42]) on the basis of transcriptomic analyses, the mechanism inducing the malformations in the mature gonads could be an autoimmune reaction triggered by 
environmental factors. The possibility that autoimmune reactions can cause gonad morphological changes of fish has already been discussed by Secombes et al. [20].

The fish in our study experienced a reduced body growth compared to wild fish in the lake. There were also growth differences between the experimental treatments. These differences were a consequence of (i) different fish densities in the tanks for which we did not correct, and (ii) different energetic values of the zooplankton and the dry food. However, it is unlikely that the growth differences had an influence on the manifestation of gonad changes. First, the prevalence of malformations did not significantly correlate with body size (Spearman correlation index $\left.r_{s}=-0.18\right)$, body weight $\left(r_{s}=-0.4\right)$, or age of fish $\left(r_{\mathrm{S}}=-0.09\right)$. Second, the zooplankton effect was still expressed when comparing the groups with the slowest growth (A12SP, Al2SD, AL2TD, Al2TP, and Bi2TP) to those with the highest growth (Al1LD, Al1SD, Bi1SD). From these findings, a correlation between growth and gonad malformations is not evident.

The finding that the development of gonad malformations of whitefish is induced by Lake Thun zooplankton leads to the question which components of the plankton are responsible for this. Principally, it could be a biochemical component of the zooplankton, or an environmental substance accumulated in or adsorbed to the plankton organisms. Biochemical changes in the natural diet as a cause of disease in wild fish have been described for a number of cases. For instance, thiamine deficiency was the causative factor of the 'M74 mortality syndrome' in Baltic salmon as well as of the 'early mortality syndrome (EMS)' in salmonids of the Great Lakes [43-45]. Similarly, an altered biochemical composition of the zooplankton was assumed to be responsable for increased mortalities and intestinal pathologies observed in larval coregonids from Lake Constance [46-48]. One factor that can cause changes in the biochemical composition of the zooplankton is an alteration of the plankton species composition. Diversity and abundance of the zooplankton in Lake Thun is continuously monitored since 1994 [49,50]. The absolute abundance of zooplankton in the lake is moderate, which reflects the oligotrophic state of the lake with a total phosphorus concentration of $<5 \mu \mathrm{g} \cdot \mathrm{L}^{-1}$. The yearly mean values are approximately 250,000 zooplankton individuals per $\mathrm{m}^{-2}$. During the growing season, zooplankton concentrations can reach values from 300,000 to 700,000 individuals per $\mathrm{m}^{2}$. The dominating zooplankton species belong to the Calanoida family (Eudiaptomus gracilis, Mixodiaptomus laciniatus), which constitute $60-90 \%$ of the yearly mean abundance of individuals $\mathrm{m}^{-2}$. Cyclopina species (mainly Cyclops abyssorum) amount for 5 to $15 \%$ and cladocerans represent 8 to $28 \%$ the number of individuals $\mathrm{m}^{-2}$. Cladocerans are mainly represented by Daphnia hyalina and Eubosmina spp., and to a lesser extent by Bythotrephes longimanus and Leptodora kindtii. According to stomach analyses of the two most abundant coregonid ecotypes in Lake Thun, 'Albock' and 'Brienzlig', cladocerans represent the main part of the ingested zooplankton [51]. Among the cladocerans, Daphnia species were found all over the year in the stomach of whitefish and often covered the major part of the diet. In late spring and summer, Bythotrephes, and to a lesser extent Leptodora, became an important food item in addition to Daphnia. In autumn and winter, the proportion of ingested calanoida species such as Eudiaptomus and Mixodiaptomus but also Cyclopina species such as Cyclops sp. increased and partly represented the major food items. New or alien zooplankton species were not found in Lake Thun to date. Overall, from these data, there is no indication of a recent change in the Lake Thun zooplankton community, which could give rise to a change in the plankton biochemical composition.

An alternative explanation to a change of the biochemical compositions of the zooplankton as inducing factor of the gonad malformations would be the accumulation of toxic substances in the plankton, such as cyanotoxins or anthropogenic contaminants. The ability of cyanotoxins to cause pathologies in fish is well documented [52,53], but the presence of cyanotoxins in Lake Thun has not yet been reported. A further argument against cyanotoxins as inducing factor of the gonad malformations is the absence of liver pathologies in the experimental fish and in coregonids collected from the lake (Bernet, unpublished), although cyanotoxins are known to cause liver pathologies in fish [54].

Apart from cyanotoxins, zooplankton is known to accumulate lipophilic anthropogenic contaminants which can be trophically transferred to zooplankton-feeding fish such as coregonids. 
The water quality of the oligotrophic Lake Thun is considered to be good. In line with this is the fact that the lake is used as a drinking water source. Effluents of wastewater treatment plants or paper mills, which have been associated with gonad alterations in fish populations elsewhere, e.g., [55-57], are not released into Lake Thun. Still, the lake water may contain microcontaminants, i.e., chemicals which occur in very low concentrations (ng to low $\mu$ g per liter range) but possess a high biological potency. Examples of such microcontaminants are endocrine-disrupting compounds (EDCs). Particularly estrogenic EDCs including natural and synthetic hormones or alkylphenols are known for their potential to cause gonad pathologies in fish $[4,16,27]$. Therefore, the water and sediments of Lake Thun were investigated for contamination by estrogenic EDCs. Bioassays performed with bile fluid and muscle tissue extracts of whitefish collected in the lake could not find any estrogenic potential in these samples [58]. Likewise, biomarkers of exposure of fish to estrogenic EDCs such as vitellogenin were not upregulated in Lake Thun whitefish, neither in fish with normal nor in fish with abnormal gonad morphology [59]. These field observations suggest that there exists no relevant exposure to estrogenic EDCs in the lake. Beyond, experimental findings indicated that the gonad morphology of whitefish is not very sensitive to estrogenic EDCs: long-term exposure of Lake Thun whitefish to $17 \beta$-estradiol did not induce Lake Thun-typical macroscopical gonad malformations, but led only to an elevated frequency of microscopic intersex [60]. In the study of Kipfer et al. [60]), the intersex prevalence of whitefish induced by experimental estrogen exposure was higher than the percentage of intersex fish found in the lake (up to 30\% intersex in the fish exposed in the laboratory to estrogens versus $<5 \%$ in wild fish from Lake Thun), a result that corroborates the findings of the biomarker and bioanalytical studies in field-sampled coregonids [58,59]. Taken together, these data suggest that estrogenic contaminants are not involved in the etiology of the gonad malformations. Other contaminants that could be associated with gonad changes in exposed fish populations include persistent organic pollutants (POPs), which are known to contaminate Lake Thun via airborne immission [61]. However, coregonids from Lake Thun contain low POP levels in their tissues and show lower POP bioaccumulation than coregonids from other Swiss and European lakes, what is not consistent with the presence of gonad malformations only in Lake Thun. Beyond, fishes with or without gonad pathologies did not differ in their POP tissue burdens [61].

Further potential sources of contaminants in Lake Thun could be deposits of ammunition, or wastewater effluents from the nearby Loetschberg tunnel works. Ammunition was deposited in Lake Thun from 1920 until 1963, when the Swiss Army dumped approximately 4600 tons. Chemical analyses on the presence of trinitrotoluene (TNT) and other selected explosives in water and sediment of Lake Thun found concentrations in the range of 0.1 to $0.4 \mathrm{ng} / \mathrm{L}[62,63])$. These explosives, however, were also present and even at four-fold higher concentrations in the water of Lake Biel [62]) where whitefish do not exhibit gonad malformations. As shown by the present experiment, gonad malformations can be induced by environmental factors in Lake Biel whitefish; thus, if the explosives were the causative factor, gonad malformations should be present in the whitefish of Lake Biel as well.

The Loetschberg tunnel works lasted from 1994 to 2006. For the construction of the tunnel, a wide range of chemical substances was used, for instance various explosives (mainly polyisobutenes) and concrete plasticizers (mainly naphthalene-sulphonates) and flocking agents for the wastewater treatment (mainly acryl amides) (Cantonal Office for Water and Soil Protection, unpublished). The wastewaters of the tunnel works are treated before release into the river Kander, from where they reach Lake Thun after a $25 \mathrm{~km}$ passage. An ecotoxicological exposure and risk analysis came to the conclusion that chemicals from the tunnel works could be a source of low-level contamination of the lake. However, the risk assessment was difficult due to the insufficient hazard data for the compounds used in the tunnel construction [64]. Experimental exposure of developing coregonids to a few selected chemicals used for the tunnel works did not result in the induction of gonad malformations [65]. Nevertheless, given the myriads of chemicals being used in the tunnel works, in partly high amounts, it cannot be excluded that contaminants from that source end up in the Lake 
Thun ecosystem and are transferred via the zooplankton into whitefish, where they may induce the development of gonad malformations.

In conclusion, coregonids are known to show high levels of phenotypic diversity, which can result from phenotypic plasticity or from genotypic adaptation $[33,35,37]$. The fact that the malformations develop during gonad sexual differentiation of $C$. spp. [66] would be in line with both mechanisms. The results of the present study provide strong evidence that the gonad changes are not genotypically but environmentally induced, more specifically, by factor(s) contained in the zooplankton of Lake Thun. This result could be confirmed in two independent experiments. Although we are not yet in a position to identify which component in the plankton is the inducing factor, the findings of the present study represent an important step forward in understanding the causes of the gonad malformations in Lake Thun whitefish populations, and they will guide the next research steps in unraveling this phenomenon.

\section{Material and Methods}

\subsection{Experimental Setup}

Testing the factor "genetics": As genitors, we used whitefish from Lake Thun and Lake Biel. In contrast to whitefish from Lake Thun, the Lake Biel coregonids do not show an increased frequency of gonad malformations [32]. Lake Biel belongs to the same catchment area as Lake Thun. It is situated $78 \mathrm{~km}$ downstream of Lake Thun (Figure 3). In Lake Thun, there exist different ecotypes of whitefish which are locally known as "Albock", "Balchen", "Brienzlig", and "Kropfer" [35,67]. All ecotypes display gonad malformations [39]. For our breeding experiments, we used the abundant, winter-spawning, pelagic ecotype 'Albock'. In Lake Biel, there are three whitefish ecotypes present. All three ecotypes of Lake Biel display no gonad malformations. For our breeding experiment, we used the "Bondelle" ecotype.

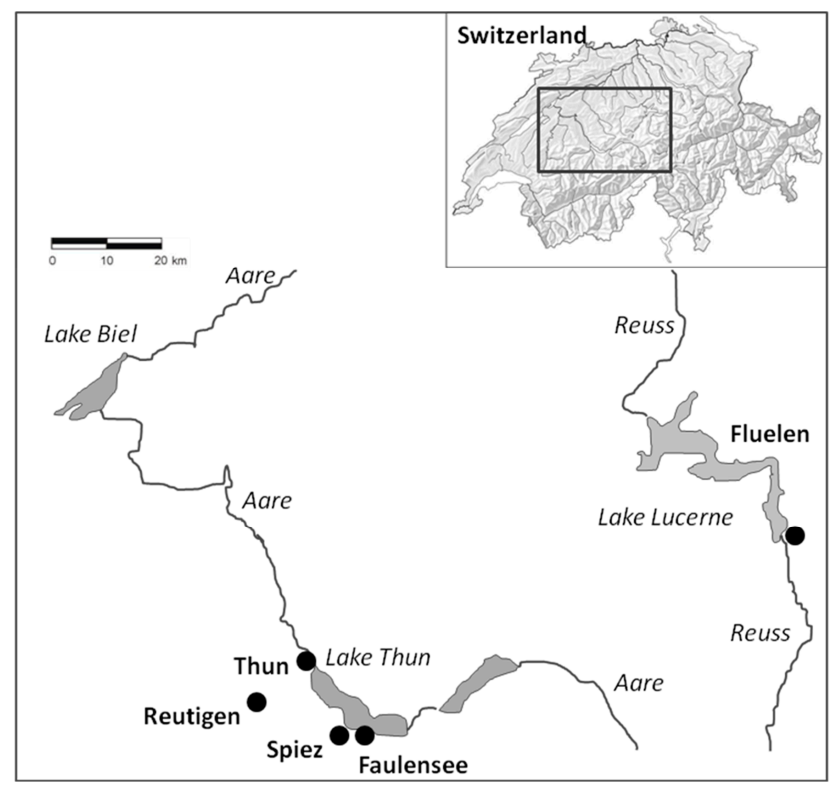

Figure 3. Map with the geographical situation of the breeding and rearing location, the lakes and the water sources. Locations in italics denotes lakes and rivers. Bold characters represent the locations of hatcheries/fish farms used for rearing fish in the experiment.

Testing the factor 'water': Three types of water were used for the rearing of the fish: water from Lake Thun, spring water, and water from Lake Lucerne, which belongs to a catchment separate from the Lake Thun catchment. Albock' whitefish from Lake Thun were reared in all three water sources, and "Bondelle" whitefish from Lake Biel were reared in Lake Thun water and in spring water. 
Testing the factor 'food': Two types of food were tested: zooplankton caught in Lake Thun (i.e., the natural diet of the fish in the lake), and commercial dry feeds.

Testing interactions: Fish of different genetic origin were exposed to the various combinations of water and food sources in order to assess whether a given set of environmental factors (water, food) in combination with one of the two genotypes is able to induce the gonad alterations.

Two potential causative factors of the gonad malformations were not considered in the present study: first, parasite infections. This factor was excluded since previous parasitological investigations did provide any evidence that fish with malformed gonads are parasitized [59]. Further, all fish sampled in the present study were analyzed for parasite infection, and we determined that they were free of parasite infection. The second factor that was not tested was the influence of the hatchery environment. Offspring of some ecotypes of Lake Thun whitefish are bred for stocking purposes in hatcheries around the lake, and it is known that hatchery practices can cause morphological variation [68]. However, since the gonad alterations are equally present in whitefish ecotypes of Lake Thun that are stocked and in ecotypes that are not stocked, it is highly unlikely that the hatchery environment has an influence.

The rearing experiments were partly replicated in two consecutive years. The various treatment groups are summarized in Figure 4. Acronyms and detailed information about the treatment groups are presented in Tables 1 and 2.

First experiment

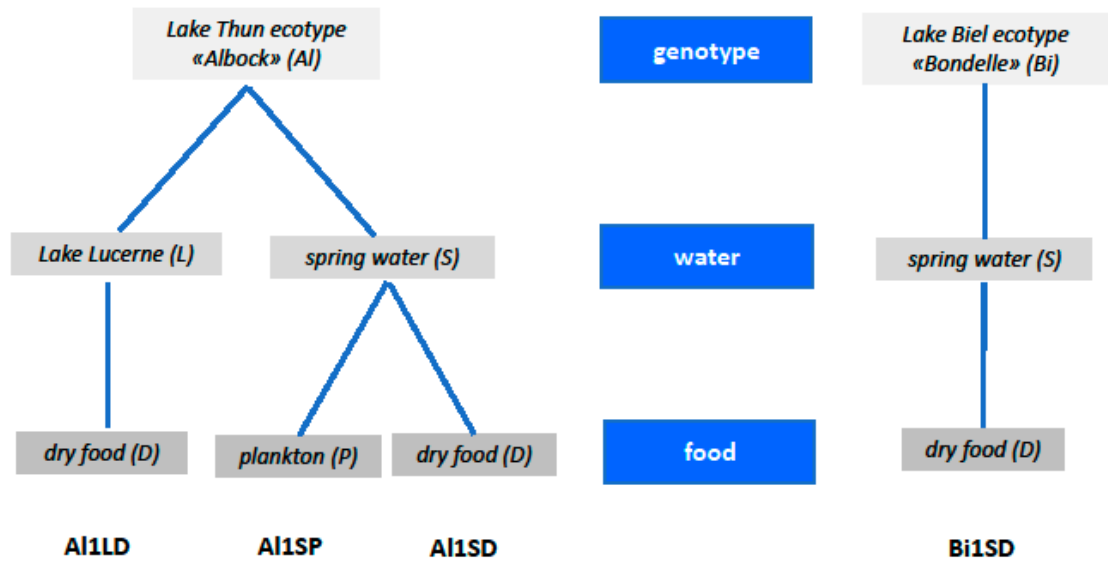

Second experiment

(a)
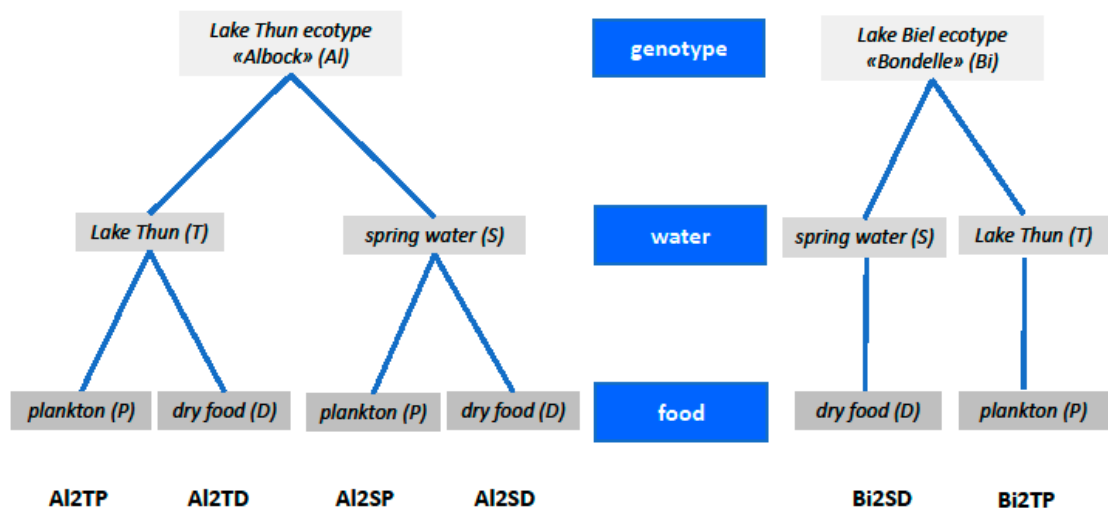

Al2TP

Al2TD

Al2SP

Al2SD

(b)

Figure 4. Experimental setup of the rearing experiment to test the factors "water" (spring water as control group; Lake Thun water; Lake Lucerne water as a second lake from another catchment area), 
"fish genetics" (fish from Lake Thun-'Albock' ecotype-and Lake Biel "Bondelle" ecotype—, "feed" (zooplankton from Lake Thun and commercial dry feed as control). Abbreviations: For the fish origin: $\mathrm{Al}=$ 'Albock' whitefish from Lake Thun; $\mathrm{Bi}=$ fish from Lake Biel. For the water quality: $\mathrm{S}=$ spring water; $\mathrm{L}=$ water from Lake Lucerne; $\mathrm{T}=$ water from Lake Thun. For the Feed: $\mathrm{D}=$ Dry feed; $\mathrm{P}=$ Zooplankton from Lake Thun. Connotations for the groups: genetic origin/water/food, i.e., Al1SD = 'Albock' whitefish from Lake Thun, reared in spring water and fed with dry feed. The indexes " 1 " and " 2 " indicate the affiliation of the treatment groups to the first experiment and the second experiment, respectively. (a) shows the treatments of the first experiment, and (b) shows the treatments of the second experiment.

\subsection{Fish Stripping, Egg Fertilization and Incubation}

The experiments started with stripping whitefish collected in either Lake Thun or Lake Biel during their spawning season in December. This procedure was designed in a way to ensure that (a) offspring of whitefish from Lake Thun and Lake Biel reared at the three locations were siblings and represented the same genetic background, and (b) fish were kept during the complete life cycle from fertilization, incubation and rearing until they reached maturity in the same source of water.

Mature coregonids were caught on their spawning places by gill netting. Fish were transported alive to the hatchery 'Faulensee' at Lake Thun, and killed by a blow on the head immediately before stripping. The area around the genital pore was dried to avoid sample contamination and prevent pre-term activation of the semen. All genitor fish were measured, weighted and dissected after stripping. The presence of gonad deformations in the genitor fish was recorded. The number of parental fish as well as the frequency of gonad deformations among them are indicated in Table 2.

For the fertilization, gametes of each fish were stripped into individual Petri dishes. Eggs from one female were paired with milt from one male. Prior to fertilization, the egg sample from each female was subdivided into equal batches for allocation to the individual treatments. Each batch of egg was fertilized with 10-50 $\mu \mathrm{L}$ milt from a single male. Sperm cells were activated by adding a few $\mathrm{ml}$ of water to the eggs in each batch. The water used for sperm activation corresponded to the water the eggs were later incubated in. After having started sperm activation, eggs in each dish were moved smoothly in circles to ensure homogenous milt repartition, and then left undisturbed for 15 to $30 \mathrm{~min}$ for swelling. Thereafter, fertilized eggs from one treatment were pooled together in containers and left undisturbed for at least another one hour for hardening. Thereafter, the containers with the fertilized eggs were transferred to the respective hatcheries, where the eggs were incubated in Zuger jars. In the hatchery 'Faulensee', the eggs were incubated in water from Lake Thun. In the nearby hatchery, 'Reutigen' the Zuger jars were supplied with spring water. In the hatchery 'Fluelen' at Lake Lucerne, the eggs were incubated in Lake Lucerne water.

\subsection{Fish Rearing}

After hatch, the fishes were transferred into circular $2000 \mathrm{~L}$ fiberglass tanks. They were reared in the same water as used for the fertilization and incubation.

Water temperatures of Lake Thun and Lake Lucerne follow seasonal variation with minimum values of $2{ }^{\circ} \mathrm{C}$ (Lake Lucerne) and $5{ }^{\circ} \mathrm{C}$ (Lake Thun), respectively. Maximum water temperature values amounted to $20^{\circ} \mathrm{C}$ (Lake Thun) and $22^{\circ} \mathrm{C}$ (Lake Lucerne). Water temperature of the spring water in the hatchery Reutigen was constantly between 8 to $8.5^{\circ} \mathrm{C}$ throughout the year. The tanks were cleaned daily and dead fish were removed. Fish density in the rearing tanks was regularly adapted in line with fish growth and biomass increase. Fish densities in the different tanks, however, were not equalized to each other. Fish of all treatment groups were reared for three years until they developed mature gonads. 


\subsection{Fish Feeding and Zooplankton Sampling}

The different treatment groups received either frozen zooplankton from Lake Thun or commercial dry feed. In the first few months, this was AgloNorse Nr.1 and Nr.2 (EWOS AS, Bergen, Norway) and thereafter Silvercup 500 to 503 (Hokovit, Bützberg, Switzerland).

Fry from Lake Thun whitefish, both those incubated in spring water and those incubated in Lake Thun water, were divided before first feeding into two equal batches to be fed with either zooplankton or dry feed. Offspring from Lake Biel whitefish reared in spring water received dry food, while their siblings reared in Lake Thun water were fed with frozen zooplankton. Lake Thun whitefish reared in Lake Lucerne water received dry food.

Zooplankton from Lake Thun was collected from mid March to the beginning of June, using a plankton net of $225 \mu \mathrm{m}$ mesh size. This mesh size was employed to exclude cyanobacteria from the samples. Collected plankton was frozen at $-20^{\circ} \mathrm{C}$. Zooplankton was sampled at four locations in Lake Thun along the northern and southern shore of the middle part of the lake. The amount of frozen plankton collected in one year sufficed to feed the fish until the plankton sampling season in the following year of the rearing trial.

\subsection{Fish Sampling and Assessment of Gonad Malformations}

Sampling took place at 964-1002 days post hatch (Table 2). In terms of day-degrees, fish of the different treatments were sampled between $8^{\prime} 296$ to $10^{\prime} 747$ degree-days (Table 2). From every treatment group, at least 200 fish were sampled - the total number of fishes sampled was 2032. Fish were euthanized with an overdose of Finquel (Argent Laboratories, Redmont, WA, USA), and afterwards measured and weighed. The gonads were dissected. The presence of malformations was assessed macroscopically, following the classification scheme of Bernet et al. [31]. For the analysis, gonad morphological alterations representing natural variability (cf. [32] and Introduction) were excluded. To assess the prevalence of microscopical intersex, which cannot be detected macroscopically, the gonads were preserved in buffered formalin, paraffin-embedded, sectioned, stained with hematoxylin-eosin and subsequently subjected to histological analyses.

\subsection{Statistics}

The original data consist of 2032 samples. When excluding the Lucerne fish, which differed in some treatment aspects from the other groups, there remained a sample size of 1785 animals. For each sample, the response variable was gonad malformations (130 malformed/1655 normal). The covariates were sex (856 males/929 females), genetic (599 "Bondelle" whitefish from Lake Biel/1186 "Albock" whitefish from Lake Thun), food regime (788 fed with Lake Thun zooplankton/997 fed with dry food), water source (1185 raised in spring water/600 raised in water of Lake Thun), age of fish in days (mean $=983, \mathrm{SD}=18)$ and the condition index (mean $=0.73, \mathrm{SD}=0.1)$.

The sample size that would be needed to detect treatment differences was calculated using the freeware program Win Episcope 2.0 [69]. The level of confidence was set to 95\%, with a power of $80 \%$. A sample size of 200 fish per tank turned out to be sufficient to reveal group differences for (a) the overall malformation frequency and (b) the particular malformation types (exceptions: intersex gonads, where more than 500 fish per tank should have been sampled to reveal group differences).

For the statistical analysis, we compared two approaches. In the first approach, differences in gonad malformation frequencies among treatment groups were analyzed using Fisher's exact test. Equality of the frequencies for gonad malformations within a treatment group received from the two trials was tested using Fisher's Combination Test for Two-Stage Sampling with the formula Chi2 $=\sum \ln (p)^{*}-2$, where $p$ represents the stochastically independent $p$-values from the pairwise treatment group testing (Fisher's exact test), calculated with data from the first and the second trial, respectively. The degrees of freedom were set at two. Statistical analyses were performed using 
Number Cruncher Statistical Systems (NCSS) 2001 and MS Excel. A $p$-value of $\leq 0.01$ instead of 0.05 was considered significant, because we did not correct for multiple testing.

In the second approach, univariate analysis was used to select the experimental variables to be integrated in a multivariate logistic regression analysis. The univariate analysis used a chi-square test for the selection of categorical variables, and a $t$-test for continuous variables. Based on this analysis, the variables selected for the logistic regression model were food, water and sex, while genetic strain was not integrated as no significant difference existed between "Bondelle" and "Albock" with respect to gonad malformations. The logistic regression identified "food" and "sex" as variables significantly influencing the response variable "gonad malformations", with an odds ratio of 6.6 for the plankton and 3.85 for the males. Overall, the findings of the two statistical approaches agreed well, and therefore we present in the text only the statistical data of the first approach.

Author Contributions: Experiment, D.B.; data analysis, D.B.; original version preparation, D.B.; data collection, D.B., C.K., and T.W.; experiments design, D.B., C.K., T.W. and H.S.; writing-manuscript draft, T.W. and H.S.; funding acquisition, H.S.; writing-final manuscript version, H.S. All authors have read and agreed to the published version of the manuscript.

Funding: This work was funded in parts by a grant from the Swiss National Science Foundation (Grant 405040-106986/1).

Acknowledgments: We thank the Fisheries Inspectorate of Bern for financial support, infrastructure facilities, sampling of whitefish from Lake Thun, and especially for their help in fish maintenance and zooplankton fishing. In particular, we would like to mention M. Flück, U. Gutmann, H. Haussener, C. Heitz, U. Lehmann, B. Rieder, M. Schmid and H. Walter. H.-U. Kernen is owed for his help in keeping fish of the Lake Thun water group. The electricity power plant Thun made us rooms available for the sampling. We thank the Office for Environmental protection of the Canton Uri for the allocation of the hatchery facilities in Fluelen for our experiments and keeping fish of the Lake Lucerne group. The commercial fishermen K. Klopfenstein, H. Moser, R. Thomann and H. Sieber helped us to obtain parental whitefish from Lake Thun, and S. Dasen und C. Dubler those from Lake Biel. D. Bittner, M. Bula, S. Furrer, S. Kipfer, M. Metselaar, B. Müller, T. Obwegeser, R. Ott and N. Wiedemar are acknowledged for their support during the sampling. We thank $C$. Largiader for his support in statistical questions and scientific advice. C. Wedekind and his group provided help with egg fertilization in the second experiment.

Conflicts of Interest: The authors declare no conflict of interest.

\section{References}

1. Porter, T.R.; Corey, S. Hermaphroditic lake whitefish, Coregonus clupeaformis, from Lake Huron. J. Fish. Res. Board Can. 1974, 31, 1944-1945. [CrossRef]

2. Scott, D.B.C. Hermaphrodite specimen of Coregonus lavaretus. from Loch Lomond, Scotland. J. Fish Biol. 1975, 7, 70. [CrossRef]

3. Hunter, J.R.; Macewicz, B.J. Rates of atresia in the ovary of captive and wild Northern anchovy. Engraulis mordax. Fish. Bull. 1985, 83, 119-136.

4. Jobling, S.; Nolan, M.; Tyler, C.R.; Brighty, G.; Sumpter, J.P. Widespread sexual disruption in wild fish. Environ. Sci. Technol. 1998, 32, 2498-2506. [CrossRef]

5. Kinnison, M.T.; Unwin, M.J.; Jira, F. Macroscopic intersexuality in salmonid fishes. NZ J. Mar. Freshw. Res. 2000, 34, 125-134. [CrossRef]

6. Blazer, V.S. Histopathological assessment of gonadal tissue in wild fishes. Fish Physiol. Biochem. 2002, 26, 85-101. [CrossRef]

7. Devlin, R.H.; Nagahama, Y. Sexc determination and sex difference in fish: An overview of genetic, physiological, and environmental influences. Aquaculture 2002, 208, 191-364. [CrossRef]

8. Körner, O.; Vermeirssen, E.L.M. Burkhardt-Holm, P. Intersex in feral brown trout from Swiss midland rivers. J. Fish Biol. 2005, 67, 1734-1740. [CrossRef]

9. Mikodina, E.V.; Sedova, M.A.; Smirnov, A.A. On abnormal gonads of the Gizhiga-Kamchatka population of the herring Clupea pallasi. J. Ichthyol. 2005, 45, 191-199.

10. Papoulias, D.M.; Chapman, D.; Tillitt, D.E. Reproductive condition and occurrence of intersex in bighead carp and silver carp in the Missouri river. Hydrobiologia 2006, 571, 355-360. [CrossRef]

11. Schwindt, A.R.; Kent, M.L.; Simonich, S.M.L.; Landers, D.H.; Blett, T.; Schreck, C.B. Reproductive abnormalities in trout from Western U.S. National Parks. Trans. Am. Fish. Soc. 2009, 138, 522-531. [CrossRef] 
12. Feist, S.W.; Stentiford, G.D.; Kent, M.L.; Ribeiro Santos, A.; Lorance, P. Histopathological assessment of liver and gonad pathology in continental slope fish from the northeast Atlantic Ocean. Mar. Environ. Res. 2015, 106, 42-50. [CrossRef] [PubMed]

13. Ojaveer, H.; Tomkiewicz, J.; Arula, T.; Klais, R. Female ovarian abnormalities and reproductive failure of autumn-spawning herring (Clupea harengus membras) in the Baltic Sea. ICES J. Mar. Sci. 2015, 72, 2332-2340. [CrossRef]

14. Rajasilta, M.; Elfving, M.; Hänninen, J.; Laine, P.; Vuorinen, U.; Paranko, J. Morphological abnormalities in gonads of the Baltic herring (Clupea harengus membras): Description of types and prevalence in the Northern Baltic Sea. Ambio 2016, 45, 205-214. [CrossRef]

15. Feist, G.W.; Webb, M.A.H.; Gundersen, G.T.; Foster, E.P.; Schreck, C.B.; Maule, A.G.; Fitzpatrick, M.S. Evidence of detrimental effects of environmental contaminants on growth and reproductive physiology of white sturgeon in impounded areas of the Columbia river. Environ. Health Persp. 2005, 113, 1675-1682. [CrossRef] [PubMed]

16. Abdel-moneim, A.; Coulter, D.P.; Mahapathra, C.T.; Sepulveda, M.S. Intersex in fishes and amphibians: Population implications, prevalence, mechanisms and molecular biomarker. J. Appl. Toxicol. 2015, 35, 1228-1240. [CrossRef]

17. Baroiller, J.F.; D'Cotta, H.; Saillant, E. Environmental effects on fish sex determination and differentiation. Sex. Dev. 2009, 3, 118-135. [CrossRef]

18. Hamaguchi, S. Bilaterally asymmetric testes in fishes of the genus Oryzias. Zool. Sci. 1996, 13, 757-763. [CrossRef]

19. Park, I.S.; Nam, Y.K.; Kim, D.S. Growth performance, morphometric traits and gonad development of induced reciprocal diploid and triploid hybrids between the mud loach (Misgurnus mizolepis Günther) and cyprinid loach (Misgurnus anguillicaudatus Cntor). Aquacult. Res. 2006, 37, 1246-1253. [CrossRef]

20. Secombes, C.J.; Needham, E.A.; Laird, L.M.; Lewis, A.E.; Priede, I.G. The long-term effects of auto-imunologically induce granulomas on the testes of rainbow trout, Salmo gairdneri Richardson. J. Fish Biol. 1985, 26, 483-489. [CrossRef]

21. Luksiene, D.; Sandström, O. Reproductive disturbance in a roach (Rutilus rutilus) population affected by cooling water discharge. J. Fish Biol. 1994, 45, 613-625. [CrossRef]

22. Yadrenkina, E.N. Appearance of hermaphrodite individuals in the crucian carp population (Carassius auratus, Cyprinida) during the regression phase of the water level in Chany lake (Western Sibiria). Limnology 2020, 21, 287-295. [CrossRef]

23. Wicklund, T.; Lounasheimo, L.; Lom, J.; Bylund, G. Gonadal impairment in roach Rutilus rutilus from Finnish coastal areas of the northern Baltic Sea. Dis. Aquat. Org. 1996, 26, 163-171. [CrossRef]

24. Harrod, C.; Griffiths, D. Parasitism, space constraints, and gonad asymmetry in the pollan (Coregonus autumnalis). Can. J. Fish. Aquat. Sci. 2005, 62, 2796-2801. [CrossRef]

25. Noaksson, E.; Tjärnlund, U.; Bosveld, A.T.C.; Balk, L. Evidence for endocrine disruption in perch (Perca fluviatilis) and roach (Rutilus rutilus) in a remote Swedish lake in the vicinity of a public refuse dump. Toxicol. Appl. Pharmacol. 2001, 174, 160-176. [CrossRef]

26. Noaksson, E.; Gustavson, B.; Linderoth, M.; Zebühr, Y.; Broman, D.; Balk, L. Gonad development and plasma steroid profiles by HRGC/HRMS during one reproductive cycle in reference and leachate-exposed female perch (Perca fluviatilis). Toxicol. Appl. Pharmacol. 2004, 195, 247-261. [CrossRef]

27. Hecker, M.; Murphy, M.B.; Coady, K.K.; Villeneuve, D.L.; Jones, P.D.; Carr, J.A.; Solomon, K.R.; Smith, E.E.; Van Der Kraak, G.; Gross, T.; et al. Terminology of gonadal anomalies in fish and amphibians resulting from chemical exposures. Rev. Environ. Contam. Toxicol. 2006, 187, 103-131.

28. Garcia, M.S.; Constantino, D.H.J.; Silva, A.P.G.; Perobelli, J.E. Fish pollutants MeHg and Aroclor cause permanent structural damage in male gonads and kidneys after prepubertal exposure. Int. J. Exp. Pathol. 2016, 97, 360-368. [CrossRef]

29. Jordanova, M.; Rebok, K.; Dragun, Z.; Ramani, S.; Ivanova, L.; Kostov, V.; Valic, D.; Krasnici, N.; Marijic, V.F.; Kapetanovic, D. Histopathology investigation on the Vadar chub (Squalius vadarenis) populations captured from the rivers impacted by mining activities. Ecotox. Environ. Saf. 2016, 129, 35-42. [CrossRef]

30. Chukwuka, A.; Ogbeide, O.; Uhunamure, G. Gonad pathology and intersex severity in pelagic (Tilpia zilli) and benthic (Neochanna diversus and Clarias gariepinus) species from a pesticide-impacted agrarian catchment, south-south Nigeria. Chemosphere 2019, 225, 535-547. [CrossRef] 
31. Bernet, D.; Wahli, T.; Kueng, C.; Segner, H. Frequent and unexplained gonadal abnormalities in whitefish (central alpine Coregonus sp.) from an alpine oligotrophic lake in Switzerland. Dis. Aquat. Org. 2004, 61,137-148. [CrossRef] [PubMed]

32. Bittner, D.; Bernet, D.; Wahli, T.; Segner,H.; Küng, C.; Largiadèr, C.R. How normal is abnormal? Discriminating between deformations and natural variation in gonad morphology of European whitefish Coregonus lavaretus (L). J. Fish Biol. 2009, 74, 1594-1614. [CrossRef] [PubMed]

33. Edge, T.A.; McAllister, D.E.; Quadri, S.U. Meristic and morphometric variation between the endangered Acadian whitefish, Coregonus huntsman, and the Lake whitefish, Coregonus clupeafomis, in the Canadian maritime provinces and the State of Maine, USA. Can. J. Fish. Aquat. Sci. 1991, 48, 2140-2151. [CrossRef]

34. Lu, G.; Bernantchez, L. Correlated trophic specialisation and genetic divergence in sympatric lake whitefish ecotpyes (Coregonus clupeaformis). Support for the ecological speciation hypothesis. Evolution 1999, 53, 1491-1505.

35. Bittner, D.; Excoffier, L.; Largiadèr, C.R. Patterns of morphological changes and hybridization between sympatric whitefish morphs (Coregonus spp.) in a Swiss lake: A role for eutrophication? Molec. Ecol. 2010, 19, 2152-2167. [CrossRef]

36. Kahilainin, K.K.; Siwertson, A.; Gjelland, K.O.; Knudsen, R.; Bohn, T.; Amundsen, P.A. The role of gill raker number variability in adaptive radiation of coregonids. Evol. Ecol. 2011, 25, 573-588. [CrossRef]

37. Volanthen, P.; Bittner, D.; Hudson, A.G.; Young, K.A.; Müller, R.; Lundsgaard-Hansen, B.; Roy, D.; Di Piazza, S.; Largiader, C.R.; Seehausen, O. Eutrophication causes speciation reversal in whitefish adaptive radiations. Nature 2012, 482, 357-362. [CrossRef] [PubMed]

38. Mikaelian, I.; de Lafontaine de, Y.; Harhsbarger, J.C.; Lee, L.L.J.; Martineau, D. Health of Lake whitefish (Coregonus clupeaformis) with elevated tissue levels of environmental contaminants. Environ. Toxicol. Chem. 2002, 21, 532-541. [CrossRef]

39. Ioannidis, J.P.A. Why most published research findings are false. PLoS Med. 2005, 2, e124. [CrossRef]

40. Kirchhofer, A. Growth characteristics of coregonid populations in three lakes with different trophic states and decreasing nutrient concentrations. Arch. Hydrobiol. Spec. Issues Advanc. Limnol. 1995, 46, 61-70.

41. Urbach, D.; Britschgi, A.; Jacob, A.; Bittner, D.; Bernet, D.; Wahli, T.; Yoccoz, N.G.; Wedekind, C. Gonadal alterations in male whitefish Coregonus fatioi: No evidence for genetic damage reducing viability in early life stages. Dis. Aquat. Org. 2008, 81, 119-125. [CrossRef] [PubMed]

42. Bittner, D.; Cossins, A.R.; Segner, H.; Excoffier, L.; Largiader, C.R. Identification of candidate genese and physiologcial pathways involved in gonad deformation in whitefish (Coregonus spp.) from Lake Thun, Switzerland. Int. J. Environ. Res. Public Health 2011, 8, 2706-2733. [CrossRef] [PubMed]

43. Börjeson, H.; Norrgren, L. M74 syndrome: A review of potential etiological factorsChemically Induced Alterations in Functional Development and Reproduction of Fishes. In Proceedings of the 1995 Wingspread Conference, Wingspread, USA, 1976; Rolland, R.M., Gilbertson, M., Peterson, R.E., Eds.; SETAC Press: Pensacola, FL, USA, 1997; pp. 153-166.

44. Fitzsimons, J.D.; Brown, S.B.; Honeyfield, D.C.; Hanth, J.G. A review of early mortality syndrome (EMS) in great lakes salmonids: Relationship with thiamine deficiency. Ambio 1999, 28, 9-15.

45. Riley, S.C.; Evans, A.N. Phylogenetic and ecological characteristics associated with thiaminase activity in Laurentian Great Lakes fishes. Trans. Amer. Fish. Soc. 2008, 137, 147-157. [CrossRef]

46. Eckmann, R.; Rösch, R.; Ortlepp, J.; Kleifeld, G. Survival and growth of coregonid larvae from Lake Constance fed on zooplankton of different origin. Arch. Hydrobiol. 1986, 22, 203-214.

47. Eckmann, R. Histopathological alterations in the intestine of whitefish (Coregonus sp.) larvae reared on zooplankton from Lake Constance. Dis. Aquat. Org. 1985, 1, 11-17. [CrossRef]

48. Eckmann, R. Pathological changes in the midgut epithelium of grayling, Thymallus thymallus L., larvae reared on different kinds of food, and their relation to mortality and growth. J. Fish Diseas. 1987, 10, 91-99. [CrossRef]

49. Guthruf, K.; Maurer, V.; Pokorni, B.; Zeh, M. Entwicklung des Phyto- und Crustaceenplanktons in Brienzer-, Thuner, Murten-, Neuenburger-und Bielersee. Amt für Wasser und Abfall, Gewässer- und Bodenschutzlabor GBL, Bern, Service de l'Environnement, Fribourg, Service de la Protection de l'Environment Neuchâtel; Kanton Bern, Cantone Fribourg: Bern, Fribourg, Switzerland, 2009; p. 112.

50. Guthruf, K.; Maurer, V.; Zeh, M. Entwicklung des Phyto- und Crustaceenplanktons in Brienzer-, Thuner, Bieler-, Neuenburger- und Murtensee. Amt für Wasser und Abfall, Gewässer- und Bodenschutzlabor GBL, Bern; Service de l'Environnement, Fribourg; Service de la Protection de l'Environnement: Neuchâtel, Switzerland, 2019; p. 87. 
51. Rufli, H. Ernährung und Wachstum der Felchenpopulationen (Coregonus spp.) des Thuner-und Bielersees. Schweiz. Zr Hydrol. 1979, 41, 64-93. [CrossRef]

52. Rodger, H.D.; Turnbull, T.; Edwards, C.; Coda, G.A. Cyanobacterial (blue-green algal) bloom associated pathology in brown trout, Salmo trutta, in Lake Lever, Scotland. J. Fish Dis. 1994, 17, 177-181. [CrossRef]

53. Ernst, B.; Hoeger, S.J.; O’Brien, E.; Dietrich, D.R. Physiological stress and pathology in European whitefish (Coregonus lavaretus) induced by subchronic exposure to environmentally relevant densities of Planktothrix rubescens. Aquat. Toxicol. 2007, 82, 15-26. [CrossRef]

54. Fischer, W.J.; Dietrich, D.R. Pathological and biochemical characterization of micocystin-indcued hepatopancreas and kidney damage in carp (Cyprinus carpio). Toxicol. Appl. Pharmacol 2000, 164, 73-81. [CrossRef] [PubMed]

55. Andersson, T.; Förlin, L.; Härdig, J.; Larsson, A. Physiological disturbances in fish living in coastal water polluted with bleached kraft pulp mill effluents. Can. J. Fish. Aquat. Sci. 1988, 45, 1525-1536. [CrossRef]

56. Lye, C.M.; Frid, C.L.J.; Gill, M.E.; McCormick, D. Abnormalities in the reproductive health of flounder Paralichthys flesus exposed to effluent from a sewage treatment works. Mar. Poll. Bull. 1997, 34, $34-41$. [CrossRef]

57. Munkittrick, K.R.; McMaster, M.E.M.; McCarthy, L.H.; Servos, M.R.; van der Kraak, G.L. An overview of recent studies on the potential of pulp mill effluents to alter reproductive parameters in fish. J. Toxicol. Environ. Health B 1998, 1, 347-371. [CrossRef]

58. Liedtke, A.; Schönenberger, R.; Eggen, R.I.L.; Suter, M.J.-F. Internal exposure of whitefish (Coregonus lavaretus) to estrogens. Aquat. Toxicol. 2009, 93, 158-165. [CrossRef]

59. Bernet, D.; Liedtke, A.; Bittner, D.; Eggen, R.I.L.; Kipfer, S.; Küng, C.; Largiader, C.; Suter, M.J.-F.; Wahli, T.; Segner, H. Gonadal Deformations in Whitefish from Lake Thun: Defining the Case and Evaluating the Role of EDCs. Chimia 2008, 62, 383-388. [CrossRef]

60. Kipfer, S.; Segner, H.; Wenger, M.; Wahli, T.; Bernet, D. Long term laboratory estrogen (E2) exposure of whitefish (central alpine Coregonus lavaretus) induces intersex but not the Lake Thun-typical gonad deformations. Dis. Aquat. Org. 2009, 84, 43-56. [CrossRef]

61. Bogdal, C.; Naef, M.; Schmid, P.; Kohler, M.; Zennegg, M.; Bernet, D.; Scheringer, M.; Hungerbühler, K. Unexplained gonad alterations in whitefish (Coregonus spp.) from Lake Thun, Switzerland: Levels of Persistent Organic Pollutants in Different Morphs. Chemosphere 2009, 74, 434-440. [CrossRef] [PubMed]

62. Berset, J.D.; Ochsenbein, U.; Zeh, M. Are Lake Thun and Lake Brienz contaminated with explosive residues? Chimia 2007, 61, 532.

63. Ochsenbein, U.; Zeh, M.; Berset, J.D. Comparing solid phase extraction and direct injection for the analysis of ultra-trace levels of relevant explosives in lake water and tributaries using liquid chromatography-electrospray tandem mass spectrometry. Chemosphere 2008, 72, 974-980. [CrossRef]

64. Brem, D.; Gälli, R. Beurteilung des Einsatzes von Bauchemikalien beim Bau der NEAT am Lötschberg-Stoffflussanalyse und grobe Abschätzung der ökologischen Risiken Short report for the Authority of Water Protection (Amt für Gewässerschutz und Abfallwirtschaft des Kantons Bern, Gewässer- \& Bodenschutzlabor. 2005. Available online: http://www.bve.be.ch/site/bve_gsa_gwq_seen_allgInfo_NEAT_ Bauchemikalien_Kurzbericht.pdf (accessed on 24 October 2019).

65. Bernet, D.; Wahli, T.; Gerecke, A.; Segner, H. Exposure of whitefish (Coregonus lavaretus) eggs to native or chemically spiked sediments from Lake Thun does not lead to abnormal gonad development. Environ.Biotechnol. 2011, 7, 17-29.

66. Bernet, D.; Wahli, T.; Kipfer, S.; Segner, H. Macroscopic gonadal deviations and intersex in developing whitefish. Coregonus Lavaretus. Aquat. Biol. 2009, 6, 1-13. [CrossRef]

67. Steinmann, P. Monographie der Schweizer Koregonen. Schweiz Zr Hydrol 1950, 12, 340-491.

68. Belk, M.C.; Benson, L.J.; Rasmussen, J.; Peck, S.L. Hatchery-induced morphological variation in an endangered fish: A challenge for hatchery-based recovery efforts. Can. J. Fish. Aquat. Sci. 2008, 65, 401-408. [CrossRef]

69. Thrushfield, M.; Ortega, C.; de Blas, I.; Noordhuizen, J.P.; Frankena, K. WIN EPISCOPE 2.0: Improved epidemiological software for veterinary medicine. Vet. Rec. 2001, 148, 567-572. [CrossRef]

(C) 2020 by the authors. Licensee MDPI, Basel, Switzerland. This article is an open access article distributed under the terms and conditions of the Creative Commons Attribution (CC BY) license (http://creativecommons.org/licenses/by/4.0/). 